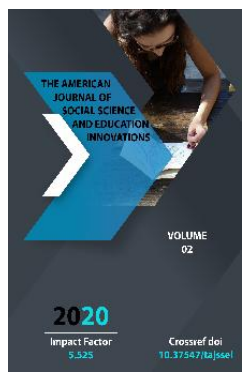

\title{
Criminal - Legislative Enforcement Of Uzbekistan: Condition, Problems And Prospects
}

\author{
Tadjibaeva Dildora Abdurahimovna \\ Phd Doctoral Student Of Faculty Of Postgraduate Education, Academy Of The Mia, Tashkent, \\ Uzbekistan.
}

Journal Website:

http://usajournalshub.c

om/index,php/tajssei

Copyright: Original

content from this work

may be used under the

terms of the creative

commons attributes

4.0 licence.

\section{ABSTRACT}

The article analyzes the criminal executive legislation of the Republic of Uzbekistan at the present stage and the prospects for its development. The best of the existing experience of criminalexecutive regulation in Uzbekistan should be preserved in the same way as the established traditions of legal engineering, language and style of the law. At the same time, in the process of drafting a new CEC of the Republic of Uzbekistan. It is advisable to resolutely abandon the provisions of "yesterday" that impede the dialogue of civil society institutions, institutions and bodies of the penitentiary system, effective educational and preventive impact on convicts, their re-socialization, respect and protection of fundamental human rights in the conditions of execution and punishment and other measures criminal law impact.

\section{KEYWORDS}

Resocialization of convicts, humanization of criminal penalties, penal system, implementation of international standards in the penal system.

\section{INTRODUCTION}

The Criminal Executive Code of the Republic of Uzbekistan consists of its General and Special Part. Legal engineering and the design of its norms and institutions as a whole do not differ from the legal engineering of the construction of criminal-executive legislation in Russia, in other states of Central Asia. At the same time, the Criminal Executive Code of the Republic of Uzbekistan (hereinafter CEC of the Republic of Uzbekistan) does not include a glossary with a list of the normative structures used. 
In the Republic of Uzbekistan, the activities of the national penitentiary system are regulated with the participation of the norms and institutions of the penal legislation. The basis of this legislation is the current Criminal Executive Code of the Republic of Uzbekistan of April 25, 1997, which includes subsequent amendments and additions. This Code, as well as the legislative acts of other Central Asian states devoted to the sphere of execution of punishments and adopted at the turn of the $X X$ - XXI centuries, retains the structure of the previous legislation of the Soviet era and some novels reflecting the state of the criminal-executive policy of the state development.

\section{RESULTS AND ITS DISCUSSION}

The current Penal Code of the Republic of Uzbekistan is the key source of legal regulation of relations for the execution of sentences and other measures of criminal law influence. In terms of its content and significance, it is a law of the "transition period", which, on the whole, has exhausted its potential in the conditions of democratic changes in society and the state in modern Uzbekistan. The Code has fulfilled its historic mission of preserving the continuity of legal institutions, traditions of legal techniques bringing together the post-Soviet states of Central Asia, in combination with separate norms implementing the principles of international legal acts on the treatment of convicts.

At the same time, many provisions of the Penal Code of Uzbekistan are outdated conceptually and do not correspond to the needs of the democratic development of the country, the political course to strengthen the image of Uzbekistan as a dynamically developing modern state. First of all, these are provisions relating to ensuring human rights in the execution of sentences, the implementation of various forms of control in the activities of the penitentiary system, the use of alternative sanctions tools, the creation of legal conditions for the implementation of modern forms and methods of educational influence as the basis for the resocialization [1] of convicts.

Criminal enforcement law is by its very nature a branch with a decisive predominance of procedural rules and institutions. In fact, this is the right procedure where procedural mechanisms should work clearly. This is just not enough in the current CEC of the Republic of Uzbekistan Many of its provisions, especially those devoted to the rights of convicts, monitoring the activities of the penitentiary system, are declarative, not having a mechanism for implementation, which greatly reduces their practical meaning. The passion of the legislator for legal casuistry and the incompleteness of the implementation of international human rights standards have in some cases led to inconsistencies between the provisions of the CEC of the Republic of Uzbekistan recommendations of these standards. Violations of legal equipment have led to the fact that the rules on the use of physical force, special means, firearms by the penitentiary staff are wording to allow broad interpretation of the grounds for such use, which not only does not comply with the key provisions of international UN standards and creates a risk of abuse in the process of using force and special means, but also damages the image of state bodies, with which the use of physical force and special means is personified. The same applies to the regulation of the use of special means for mentally ill prisoners. Unfortunately, in the 
CEC of the Republic of Uzbekistan there are no provisions implementing the rule of the Nelson Mandela Rules[2] that "... the prison administration is recommended to use, as far as possible, conflict prevention mechanisms, mediation or any other alternative dispute resolution methods to prevent disciplinary violations or conflict resolution" (Rule 38). The presence of such an implementation in the "letter" or "in the spirit" would make it possible to consolidate the grounds for the use of force, special means, and especially firearms, as truly exceptional, dictated by extreme necessity.

The current CEC of the Republic of Uzbekistan pays insufficient attention to procedural issues of handling and resolving complaints of convicts, little touches the possibility of judicial appeal by convicts of disciplinary punishments, refusal to leave the correctional facilities due to exceptional circumstances, which does not help minimize conflicts between convicts and the prison administration.

Unfortunately, not reflected in CEC of the Republic of Uzbekistan the peculiarities of ensuring decent conditions for serving sentences of imprisonment by convicted persons of vulnerable categories. Norms about minors, about women prisoners, about people with disabilities, about people with mental disorder in CEC of the Republic of Uzbekistan there are, however, they very incompletely reveal the problems of these persons. There are also no real guarantees for the protection of female prisoners from sexual and other violence. In fairness, it should be noted that these are not only the problems of the CECs of Uzbekistan, but also the penitentiary codes of other Central Asian states. But in the CEC of the Republic of Uzbekistan some categories of vulnerable prisoners are not mentioned at all. This, in particular, HIV-infected and AIDS patients. If we assume that such, even in small numbers, are held in penitentiary institutions, there is a risk that they are attributed (can be attributed) to convicts suffering from infectious diseases, and subjected to discriminatory isolation from other convicts to imprisonment.

]The current CEC of the Republic of Uzbekistan, as noted earlier, proclaims the consideration of generally accepted norms and principles of international law, the priority of international treaties over the norms of national criminal-executive legislation. However, the most important provisions of international standards relating to the protection of human dignity, the inadmissibility of torture and ill-treatment are practically not mentioned in the foundations of the legal status of convicts in CEC articles of the Republic of Uzbekistan regulating various legal restrictions and coercive measures carried out by prison officers in correctional institutions.

In the current CEC of the Republic of Uzbekistan there is no legal basis for exercising public control over the activities of penitentiary institutions, which disagrees not only with the recommendations of UN international legal acts, but also with the experience of many modern states in the implementation of public oversight reasonably allowing to improve the correctivepreventive activities of the penitentiary system institutions.

The current CEC of the Republic of Uzbekistan practically does not contain the norms devoted to the regulation of educational influence on those sentenced to punishment without imprisonment. There is no algorithm 
for participation in this process (and in a wider context - the process of re-socialization) of civil society institutions and its resources, including those related to the social, cultural and spiritual traditions of the society in Uzbekistan. At CEC of the Republic of Uzbekistan there are no criteria for the correction of convicts, no tools are used to create conditions for the re-socialization of convicts, taking into account the world experience in the use of probation. This is not conducive to the effectiveness of the application of the penal law. In the part related to the resocialization of convicts, including in the case of punishments and other measures alternative to deprivation of liberty, it is necessary to strengthen qualitatively in the criminal-executive legislation.

Certain shortcomings of the legal technique and pithiness of the context in the current CEC of the Republic of Uzbekistan, which are addressed in this expert study, can be resolved "article by article" - by making changes and additions to the existing Penal Code. However, conceptual changes and the adoption of a new CEC of the Republic of Uzbekistan are more preferable.

The democratic choice of development of Uzbekistan and the priority of ensuring and protecting human rights and freedoms on the basis of the rule of law consistently leads to humanize national criminal law.

Our society at the turn of the XXI century has undergone a gigantic transformation, due to both socio-political and economic transformations in the state. The transformation that has taken place in society has affected all spheres of public life, including the country's penitentiary system, and demanded the reorganization of all state structures, including a change in the methodological foundations of their activities. In this aspect, numerous transformations were carried out and a new model for managing the penitentiary system was built.

By the Decree of the President of the Republic of Uzbekistan dated February 7, 2017, the "Action Strategy for the Five Priority Development Areas of the Republic of Uzbekistan in 2017-2021" was adopted. In accordance with the decree, one of the priorities for improving the system of state and social construction is "ensuring the rule of law and further reforming the judicial system", including the improvement and liberalization of criminal and criminal procedure legislation, decriminalization of individual criminal acts, humanization of criminal penalties and the procedure for their implementation (clause 2.3 of the "Strategy for Action"), as well as "the development of modern forms of implementation of public control for, increasing the efficiency of social partnership ", which implies interaction, cooperation of state bodies and civil society institutions; the need to develop civil society institutions, increase their social and political activity (Section 1.3).

"The state program for the implementation of the Action Strategy in the five priority areas of development of the Republic of Uzbekistan in 2017-2021", in 2018, among other things, was tasked: "Introduction of additional mechanisms to ensure the rights of prisoners, widespread introduction of international standards in the system of execution of punishments "(Paragraph 59), providing for the development and approval of the concept of the criminal-executive legislation for 20182021. 


\section{CONCLUSION}

So, to further strengthen measures to improve the penitentiary system, systematize and harmonize the norms of the penitentiary legislation, by the resolution of the President of the Republic of Uzbekistan dated November 7, 2018, the "Concept of improvement of the penitentiary legislation of the Republic of Uzbekistan in 2019-2021" was adopted, where the following tasks prevail:

- Expanding the base of normative legal acts on the basis of the inventory of criminal-executive legislation for its compliance with international standards;

- Exclusion of rules allowing for different interpretations or manifestations of corruption or requiring clarification on their application, as well as a full transition to the practice of applying laws of direct action;

- Clear definition and ensuring a uniform application of the legal meaning of terms and concepts used in the criminalexecutive legislation;

- Improvement of legal mechanisms for ensuring public control over the activities of institutions and bodies that execute punishments and other measures of legal influence;

- Further improvement of the principles, procedure and conditions of criminal law impact, taking into account modern approaches, advanced international standards and foreign practices;

- Creation of a system for automated registration of convicts held in penitentiary institutions;

- Determination of the legal framework for the functioning of the probation units, mechanisms and authorities for the implementation of their assigned tasks and functions;
- The introduction of the order of the chamber type of the maintenance of convicts in the institutions for the execution of punishment alternatively collective form of content;

- Development and implementation of criteria for evaluating the activities of employees of probation units and institutions for the execution of sentences;

- Unification of the norms of the criminalexecutive legislation.

The end result of the implementation of the Concept should be the correction of convicts, the prevention of their criminal activities, as well as the organization of the effectiveness of the system for preventing the commission of crimes by others.

\section{REFERENCES}

1. Resocialization can be defined also as a process by which individuals, defined as inadequate according to the norms of a dominant institution, are subjected to a dynamic redistribution of those values, attitudes and abilities to allow them to function according to the norms of the said dominant institutions. That definition relates more to a jail sentence. If individuals exhibit deviance, society delivers the offenders to a total institution, where they can be rehabilitated.

2. The Nelson Mandela Rules - the minimum standard rules for the treatment of prisoners (adopted at the 1st UN Congress in 1955 in Geneva), later they were named after the human rights activist N. Mandela. 